\title{
Short-chain free fatty acid receptors FFA2/GPR43 and FFA3/GPR41 as new potential therapeutic targets
}

\section{Trond Ulven * \\ Department of Physics, Chemistry and Pharmacy, University of Southern Denmark, Odense, Denmark}

\section{Edited by:}

Nicola J. Smith, Victor Chang

Cardiac Research Institute, Australia

\section{Reviewed by:}

Nicholas D. Holliday, University of

Nottingham, UK

Leigh Stoddart, University of

Nottingham, UK

\section{*Correspondence:}

Trond Ulven, Department of Physics, Chemistry and Pharmacy, University of Southern Denmark, Campusvej 55, DK-5230 Odense M, Denmark. e-mail:ulven@sdu.dk
The deorphanization of the free fatty acid (FFA) receptors FFA1 (GPR40), FFA2 (GPR43), FFA3 (GPR41), GPR84, and GPR120 has made clear that the body is capable of recognizing and responding directly to nonesterified fatty acid of virtually any chain length. Colonic fermentation of dietary fiber produces high concentrations of the short-chain fatty acids (SCFAs) acetate, propionate and butyrate, a process which is important to health. The phylogenetically related 7-transmembrane (7TM) receptors free fatty acid receptor 2 (FFA2) and FFA3 are activated by these SCFAs, and several lines of evidence indicate that FFA2 and FFA3 mediate beneficial effects associated with a fiber-rich diet, and that they may be of interest as targets for treatment of inflammatory and metabolic diseases. FFA2 is highly expressed on immune cells, in particular neutrophils, and several studies suggest that the receptor plays a role in diseases involving a dysfunctional neutrophil response, such as inflammatory bowel disease (IBD). Both FFA2 and FFA3 have been implicated in metabolic diseases such as type 2 diabetes and in regulation of appetite. More research is however required to clarify the potential of the receptors as drug targets and establish if activation or inhibition would be the preferred mode of action. The availability of potent and selective receptor modulators is a prerequisite for these studies. The few modulators of FFA2 or FFA3 that have been published hitherto in the peer-reviewed literature in general have properties that make them less than ideal as such tools, but published patent applications indicate that better tool compounds might soon become available which should enable studies critical to validate the receptors as new drug targets.

Keywords: 7TM receptors, free fatty acids, GPCR, inflammation, metabolic diseases, short-chain fatty acids, type 2 diabetes

\section{INTRODUCTION}

Fatty acids, mostly in esterified form, make up a fundamental component in biology. It has long been recognized that certain nonesterified fatty acids are involved in regulation of metabolism and the immune system, for example, by conversion of arachidonic acid to potent signaling substances such as prostaglandins and leukotrienes. The realization that saturated or unsaturated free fatty acids (FFAs) of virtually any length can act directly as signaling molecules through cell surface receptors is however much more recent, and came with the identification of the 7-transmembrane receptors FFA1, FFA2, FFA3, GPR84, and GPR120, all activated by FFAs of various chain length.

In 1997, the genes GPR40, GPR41, GPR42, and GPR43 were discovered in the course of a search for novel subtypes of the unrelated galanin receptor (Sawzdargo et al., 1997). The deorphanizations of the corresponding receptors GPR40, GPR41, and GPR43 were reported in 2003, when it became clear that they all respond to FFAs (Briscoe et al., 2003; Brown et al., 2003; Kotarsky et al., 2003; Le Poul et al., 2003; Nilsson et al., 2003), and the receptors were later renamed to FFA1, FFA3, and FFA2, respectively (http://www.iuphar.org/). GPR42 was first believed to be an inactive pseudogene, but was recently found to be a functional polymorph of GPR 41 with $98 \%$ overall identity and $100 \%$ identity in the transmembrane (TM) domains (Liaw and Connolly,
2009). Subsequently, the phylogenetically distinct FFA receptors GPR84 and GPR120 have been identified (Hirasawa et al., 2005; Wang et al., 2006).

FFAs are generally divided into short-chain fatty acids (SCFAs), consisting of 1-6 carbon atoms, medium-chain fatty acids (MCFAs), with 7-12 carbon atoms, and long-chain fatty acids (LCFAs), with more than 12 carbon atoms. FFA1 (GPR40) is highly expressed in the pancreatic $\beta$-cells and is activated by saturated and unsaturated LCFAs and to a less extent by MCFAs, resulting in enhancement of glucose-stimulated insulin secretion, and was thus identified as a new potential target for treatment of type 2 diabetes (Itoh et al., 2003). This observation has attracted much attention, and several series of FFA1 ligands have been identified (Briscoe et al., 2006; Garrido et al., 2006; Song et al., 2007; Christiansen et al., 2008, 2010, 2011, 2012; Tan et al., 2008; Tikhonova et al., 2008; Humphries et al., 2009; Negoro et al., 2010, 2012; Sasaki et al., 2011; Houze et al., 2012; Mikami et al., 2012), of which the most advanced compound has demonstrated good efficacy in phase II studies and currently undergoes phase III clinical trials (Burant et al., 2012). GPR84 and GPR120 respond to MCFAs and LCFAs, respectively. These receptors have so far received less attention than FFA1 as potential drug targets, even though activation of GPR120 is associated with release of glucagon-like peptide-1 (GLP-1), increased insulin sensitivity 
and repression of macrophage-induced inflammation (Hirasawa et al., 2005; Oh et al., 2010). The recent finding that dysfunctional GPR120 lead to obesity in both mouse and human is expected to attract more attention to this receptor (Ichimura et al., 2012). Only a few ligands with moderate potency have until now been published on GPR84 and GPR120 (Briscoe et al., 2006; Wang et al., 2006; Suzuki et al., 2008). The first potent and selective GPR120 agonist was disclosed only recently (Shimpukade et al., 2012). In contrast to the other fatty acid receptors, FFA2 and FFA3 are activated by SCFAs. The receptors are phylogenetically related to FFA1, and pharmacological profiles of the three receptors have been thoroughly discussed in several excellent reviews (Brown et al., 2005; Covington et al., 2006; Milligan et al., 2006; Hirasawa et al., 2008; Stoddart et al., 2008b; Ichimura et al., 2009; Wellendorph et al., 2009; Hudson et al., 2011). This review will focus on the potential roles of the SCFA receptors FFA2 and FFA3 as targets for discovery of new therapeutics, and the currently known ligands for the receptors will be examined.

\section{THE POTENTIAL ROLES OF FFA2 AND FFA3 AS DRUG TARGETS}

FFA2 and FFA3 were deorphanized simultaneously by three independent groups (Brown et al., 2003; Le Poul et al., 2003; Nilsson et al., 2003). The receptors are activated by high micromolar or millimolar concentrations of SCFAs, most notably acetate, propionate and butyrate, which are produced in total concentrations up to above $100 \mathrm{mM}$ by colonic fermentation of dietary fiber (Topping and Clifton, 2001). FFA3 responds somewhat more strongly to the longer SCFAs, thus, formic acid (C1) and acetic acid (C2) exhibit higher potency at the human FFA2, whereas valeric acid (C5) and caproic acid (C6) have higher potency at hFFA3 (Brown et al., 2003; Le Poul et al., 2003). Although FFA2 and FFA 3 were deorphanized about at the same time as FFA1, they have until now received less attention as drug discovery targets. One likely reason for this is that the indications that can be targeted by FFA2 and FFA3 have been less clear-cut than for FFA1.

\section{FFA2}

FFA2 is expressed most highly in immune cells such as peripheral blood mononuclear cells (PBMC) and polymorphonuclear cells (PMN) with an especially high expression found in neutrophils (Brown et al., 2003; Le Poul et al., 2003; Nilsson et al., 2003). Several studies have demonstrated that FFA2 mediates the chemotactic effects of SCFAs on neutrophils (Le Poul et al., 2003; Maslowski et al., 2009; Sina et al., 2009; Vinolo et al., 2011). These observations suggested that FFA2 could be of interests for treatment of diseases associated with an excessive or defect neutrophil response, such as inflammatory bowel disease (IBD) or alcoholism-associated immune depression.

A high intake of fiber is associated with decreased risk of and beneficial effects on the IBDs ulcerative colitis and Crohn's disease (Hou et al., 2011). The recent observation that FFA2-deficient mice show exacerbated or unresolving inflammation in models of colitis, arthritis and asthma, and that germ-free wild-type mice, unable to convert fiber to SCFAs, show similarly exacerbated inflammatory conditions, indicate that SCFAs and FFA2 represents a link between a fiber-rich diet and its beneficial effects on the immune system and inflammation (Maslowski et al., 2009). These observations suggest that FFA2 agonists could be of interest for the treatment of IBD. On the other hand, FFA2knockout mice exhibited diminished inflammatory response to dextrane sodium sulfate-induced colitis, a common model of IBD, and in particular exhibited reduced infiltration of PMNs (Sina et al., 2009). These results indicate that antagonists of FFA2 could have a role in treatment of intestinal inflammation. PMNs however also protect against bacterial infection or translocation, and there is a risk that FFA2 antagonists might interfere with these protective effects. Thus, although a link between FFA2 and IBD has been established, it is at present unclear if agonists or antagonists of FFA2 would be the preferred treatment. A recent study found elevated expression of FFA2 and FFA3 in fetal membranes and placenta after onset of labor, and that treatment of amnion explants with LPS significantly increased FFA2 expression, whereas co-treatment with LPS and propionate reduced the inflammatory response (Voltolini et al., 2012). These results suggest that FFA2 agonists could reduce maternal and fetal inflammation and might counteract preterm labor triggered by this.

It is known that SCFAs have tumor suppressive properties, effects that have been explained e.g., by inhibition of histone deacetylase (Medina et al., 1997). A recent report shows that FFA2 expression frequently is reduced or lost in colon cancer cells (Tang et al., 2011). Restoration of FFA2 expression in the tumor cells followed by propionate treatment induced G0/G1 cell cycle arrest, activated caspases, upregulated p21, decreased cyclin D3 and cyclin dependent kinases 1 and 2, and increased apoptotic cell death (Tang et al., 2011). The results suggest that FFA2 functions as a tumor suppressor and provides a possible mechanism for the putative connection between a high-fiber diet and lower incidence of colon cancer.

FFA2 has also been proposed to play a role in regulation of appetite and metabolism (Sleeth et al., 2010). A fiber-rich diet is linked to lower body weight and lower incidence of diabetes (Psaltopoulou et al., 2010), and some evidence indicates that SCFAs produced by colonic fermentation of fiber may be responsible for this through FFA2 (Sleeth et al., 2010). High-fiber diets are associated with increased levels of peptide YY (PYY), a hormone known to decrease appetite (Karra and Batterham, 2010). FFA2 is found to be expressed in enteroendocrine $L$ cells, responsible for PYY secretion (Karaki et al., 2006, 2008). The L cells are also responsible for GLP-1 secretion, a potent anorectic incretin hormone which also regulate insulin secretion from pancreatic $\beta$-cells and increase insulin sensitivity in target tissue. It was recently demonstrated that expression of FFA2 and FFA3 is enriched in L cells and that FFA2 mediate SCFA-promoted GLP1 release from mixed colonic cultures in vitro (Tolhurst et al., 2012). These observations indicate that FFA2 agonists can have potential as therapeutics for treatment of type 2 diabetes and related metabolic conditions. FFA2 is also expressed in the murine pancreatic $\beta$-cell line MIN6 and isolated mouse islets (Kebede et al., 2009; Halpern et al., 2012), but the role of the receptor in $\beta$-cells is still unclear.

Also related to the effects of dietary fiber on body weight are the observations that FFA2 is expressed in murine adipose 
tissue and that acetate and propionate affect adipogenesis and adipocyte differentiation through FFA2 in mice (Hong et al., 2005). Activation of FFA2 furthermore leads to inhibition of lipolysis and suppression of plasma FFAs without the flushing associated with nicotinic acid, and the receptor may thus represent a target for treatment of dyslipidemia (Ge et al., 2008). The beneficial effects on high density lipoprotein (HDL) levels observed after moderate alcohol consumption might be at least partially a consequence of acetate, a metabolite of ethanol, on FFA2. A recent study found that FFA2-deficient mice on a high-fat diet exhibited improved glucose control, reduced body fat mass and increased insulin sensitivity, indicating that FFA2 antagonists might be of interest for treatment of metabolic disorders (Bjursell et al., 2011). Another recent study found that inulin-type fructans, known to counteract high-fat diet-induced obesity and other metabolic disorders, inhibited the FFA2 overexpression in adipose tissue normally seen with high-fat diets (Dewulf et al., 2011).

Thus, several lines of evidence link FFA2 to food intake, body weight and metabolic disorders such as type 2 diabetes. More research is however required to firmly conclude that FFA2 is an attractive target for these conditions and clarify if agonists or antagonists will be the preferred mode of treatment.

\section{FFA3}

FFA3 was deorphanized independently by two groups (Brown et al., 2003; Le Poul et al., 2003). Both groups found FFA3 mRNA broadly expressed in various tissue, including pancreas, PBMC, spleen and adipose. Brown and co-workers found especially high levels of FFA3 mRNA in human adipose tissue and confirmed high expression in white adipose tissue with immunohistochemistry using an antibody specific for hFFA3 and hGPR42 (Brown et al., 2003). Subsequently, expression of FFA3 in both human and mouse adipose tissue was confirmed and it was found that SCFAs stimulate production of the anorexigenic hormone leptin in primary mouse white adipose tissue through FFA3 (Xiong et al., 2004). Hong and co-workers (2005) were however unable to detect FFA3 in murine adipose tissue or 3T3-L1 adipocytes, but found high levels of FFA2. They found that blocking FFA2 expression with siRNA blocked adipocyte differentiation, and concluded that the effects of SCFAs on adipocytes in mice are mediated through FFA2 rather than FFA3 (Hong et al., 2005). This conclusion was supported by Zaibi and co-workers (2010), who also failed to detect FFA3 mRNA in mouse adipose tissue and furthermore observed that FFA2 expression was consistently reduced in adipose tissue of FFA3 knockout mice compared to wild type mice. They confirmed SCFA-promoted leptin secretion in wild-type mice and reduced secretion in the FFA3 knockout mice, an effect which was explained by concomitant downregulation of FFA2 in the FFA3 knockouts (Zaibi et al., 2010). These observations underline the need for selective tool compounds in the further study of these receptors.

Like FFA2, FFA3 is expressed in enteroendocrine cells secreting the satiety hormone PYY and may be implicated in its release (Karaki et al., 2006). The receptor is also, like FFA1 and FFA2, expressed in pancreatic $\beta$-cells (Kebede et al., 2009; Halpern et al., 2012), but its role in these cells is at present unclear, although a patent application indicates that FFA3 agonists inhibit insulin secretion (see below). Samuel and co-workers found FFA3knockout mice to be significantly leaner than wild-type mice. The difference disappeared in germ-free mice, indicating that the effect depends on SCFAs produced by fermentation. Deletion of FFA3 was associated with reduced secretion of PYY, but without affecting the amount of chow consumed by the mice. This led the authors to suggest that the reduction in weight is a result of the increased gut motility by the lower PYY level, leading to a reduced uptake of SCFAs (Samuel et al., 2008). The lean phenotype of FFA3 knockout mice is inconsistent with its suggested role as mediator of leptin secretion. However, Zaibi et al. (2010) mention unpublished observations that male FFA3 knockout mice are obese rather than lean.

SCFAs and ketone bodies are found to regulate the sympathetic nervous system directly through FFA3 at the sympathetic ganglion. SCFAs stimulate the sympathetic outflow by activating FFA3, whereas $\beta$-hydroxybutyrate (1, Figure 1), a metabolite produced during the ketogenic state of starvation or diabetes, antagonize FFA3 and thereby suppress the sympathetic nervous system (Kimura et al., 2011). Thus, FFA3 appears to contribute to sympathetic activation in the fed state when glucose is the main fuel and abundant production of SCFAs by colonic fermentation of dietary fiber take place, whereas the receptor contributes to energy conservation under ketogenic conditions during fasting. This observation implicates that FFA3 agonists could represent a potential treatment of obesity.

Several studies have connected FFA3 with metabolic regulation and energy expenditure, but expression in adipose tissue is controversial and the overall function of the receptor is still unclear. Further research is therefore required to clarify the picture and selective tool compounds would be highly valuable to this research.

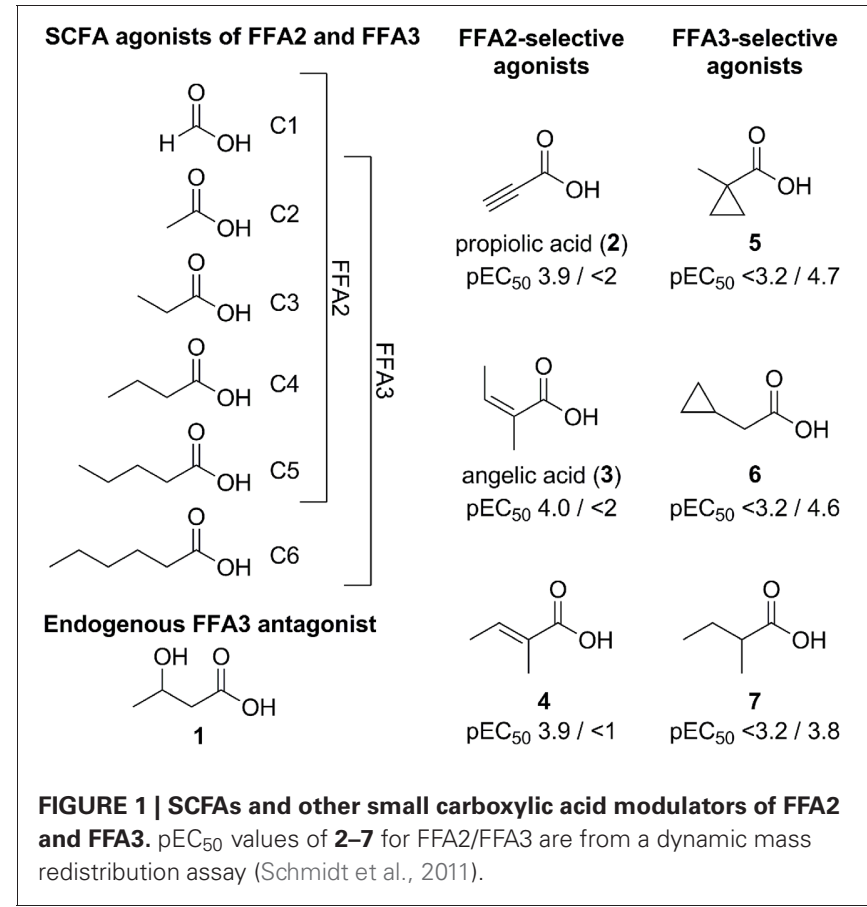




\section{LIGANDS F0R FFA2 AND FFA3}

Although it is a decade since FFA2 and FFA3 were deorphanized, few ligands have been reported for the receptors. The initial publications disclosed $\mathrm{EC}_{50}$ values for SCFAs in the high micromolar and low millimolar range, corresponding to physiological concentrations (Brown et al., 2003; Le Poul et al., 2003; Nilsson et al., 2003). The potency rank order of SCFAs for FFA2 is acetate (C2) $\sim$ propionate $(\mathrm{C} 3)>$ butyrate $(\mathrm{C} 4)>$ valerate $(\mathrm{C} 5)>$ formate (C1). The corresponding rank order for FFA3 was somewhat different, with propionate $(\mathrm{C} 3) \sim$ butyrate $(\mathrm{C} 4) \sim$ valerate $(\mathrm{C} 5)>$ acetate $(\mathrm{C} 2)>$ caproate $(\mathrm{C} 6)$. Thus, FFA2 has a preference for the shorter SCFAs, whereas FFA3 prefer the longer SCFAs, with propionate (C3) being among the most potent SCFA for both receptors (Figure 1).

By site-directed mutagenesis, an arginine residue near the top of TM helix 5 and another arginine at the top of TM 7 were found to be critical for the recognition of SCFAs for both FFA2 $\left(\operatorname{Arg} 180^{5.39}, \operatorname{Arg} 255^{7.35}\right)$ and FFA3 (Arg185 $5^{5.39}, \operatorname{Arg} 258^{7.35}$ ) (Figure 2) (Stoddart et al., 2008a). Two corresponding residues in FFA1 (Arg183 $3^{5.39}$ and Arg258 7.35 ) are likewise critical for recognition of LCFAs (Sum et al., 2007). Thus, the two arginines function as conserved anchoring residues for the fatty acid carboxylate group throughout the FFA1-3 receptor subfamily. In addition, the mutation His(VI:20/6.55)Ala in hFFA2 or hFFA3 eliminated the response to SCFAs (Stoddart et al., 2008a). The corresponding residue in FFA1, Asn $244^{6.55}$, is also critical for FFA recognition. Furthermore, mutation of His $146^{4.56}$ to alanine eliminated SCFA response in FFA3, whereas the corresponding mutations in FFA2 (His140 ${ }^{4.56}$ ) or FFA1 (His136 ${ }^{4.56}$ ) only reduced the response to SCFAs and LCFAs, respectively (Sum et al., 2007; Stoddart et al., 2008a). Thus, the recognition of the fatty acid carboxylate group appears to take place by a conserved mechanism in FFA1, FFA2, and FFA3.

The low potency and selectivity of the SCFAs on FFA2 and FFA3 make them difficult starting points for optimization and generally unsuitable as pharmacological tool compounds. However, when their size is taken into account, the potency of acetate and propionate on these receptors is quite impressive and ligand efficiency calculations indicate that it is unrealistic to expect higher potency without significantly increasing the size of the compounds (Schmidt et al., 2011). To explore the structureactivity relationships around the SCFAs on FFA2 and FFA3, a diverse selection of small carboxylic acids with lipophilic tails, including branched, cyclic and unsaturated, were selected and

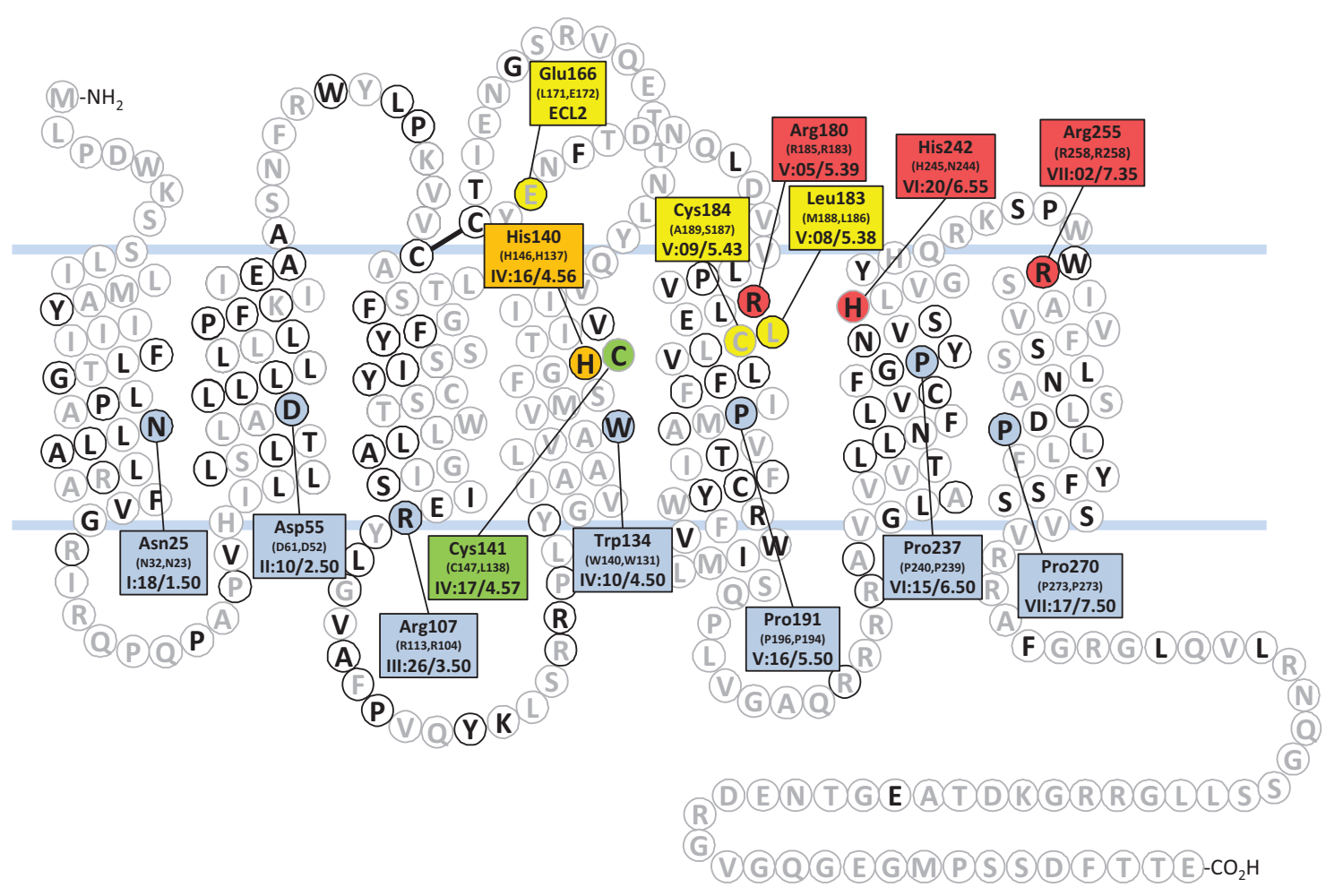

FIGURE 2 | Snake plot of the human FFA2. Residues with black letters are conserved between hFFA2 and hFFA3. Residues in black circles are conserved between hFFA2 and hFFA1. Highlighted hFFA2 residues are identified in the connected squares, the corresponding residues of hFFA3 and hFF1 are given in parenthesis, and Schwartz-Baldwin (Rosenkilde et al., 2010) and Ballesteros-Weinstein (Ballesteros and Weinstein, 1995) notations for TM residue positions are indicated. The most conserved residue of each helix throughout family A of the 7TM receptors are blue. The two arginines and the histidine critical for recognition of SCFAs in FFA2 (R180, H242, R255) and FFA3 (R185, H245, R258) are red and the histidine important for SCFA recognition in FFA2 $(\mathrm{H} 140)$ and critical in FFA3 $(\mathrm{H} 146)$ is orange (Stoddart et al., 2008a). The three residues that reverse the selectivity for $\mathbf{4}$ and $\mathbf{5}$ when swapped (FFA2: E166L, L183M, C184A; FFA3: L171E, M188L, A189C) are yellow (Schmidt et al., 2011). The cysteine that enables hFFA2 to be activated by longer FFAs when mutated to glycine is green (Hudson et al., 2012). 
characterized on hFFA2 and hFFA3. None of the compounds exhibited higher potency than the most potent SCFAs, but the study resulted in the elucidation of a general rule for predicting the selectivity of small carboxylic acids for FFA2 or FFA3: Ligands with substituted $\mathrm{sp}^{3}$-hybridized $\alpha$-carbons preferentially activate FFA3, while ligands with $\mathrm{sp}^{2}$ - or $\mathrm{sp}$-hybridized $\alpha$-carbons prefer FFA2 (Schmidt et al., 2011). For example, propiolic acid (2), angelic acid (3) and (E)-2-methylcrotonic acid (4) are all at least 10-100-fold selective for hFFA2 over hFFA3, whereas 1-methylcyclopropanecarboxylic acid (5), cyclopropylacetic acid (6) and 2-methylbutyric acid (7) have distinct selectivity for hFFA3 over hFFA2 (Figure 1). The compounds were inactive on the $\operatorname{Arg}(\mathrm{V}: 05 / 5.39)$ Ala and $\operatorname{Arg}(\mathrm{VII}: 01 / 7.35)$ Ala mutants, confirming interaction at the orthosteric binding site. Moreover, by swapping three nonconserved amino acid residues between FFA2 and FFA3 (Figure 2), the selectivity of $\mathbf{4}$ and $\mathbf{5}$ was inverted (Schmidt et al., 2011). This thorough understanding of the binding site interaction and selectivity of the small carboxylic acids makes a good basis for using these structures in the discovery of selective FFA2 and FFA3 ligands, for example in a fragment-based approach.

The bovine FFA2 is less sensitive to the shortest SCFAs and responds most strongly to caproic acid (C6), probably reflecting a digestion adapted for non-digestible carbohydrates and higher levels of SCFAs (Hudson et al., 2012). Mutation of Cys $141^{4.57}$ in hFFA2 (Figure 2) to the Gly corresponding to the bovine receptor transferred a similar ligand selectivity to the human receptor. By introducing a second $\mathrm{H} 242 \mathrm{Q}$ mutation in hFFA2, the receptor lost its response to SCFAs, which was taken advantage of in the construction of a receptor activated solely by a synthetic ligand (RASSL) of FFA2 (Hudson et al., 2012).

Amgen has described two closely related phenylacetamides as allosteric agonists of FFA2 (Figure 3). The compounds are completely selective for FFA2 over FFA3 and FFA1, produce full agonistic response alone, and act in a positively cooperative fashion with acetate or propionate. Both compounds were shown to activate $\mathrm{G} \alpha_{\mathrm{i}}$ and $\mathrm{G} \alpha_{\mathrm{q}}$ pathways and to inhibit lipolysis in adipocytes (Lee et al., 2008). The racemic compound (rac-8) was identified by high-throughput screening, of which the (S)-enantiomer AMG7703 (8, Figure 3) was found to be responsible for the activity. Mutational studies have been performed to identify the binding mode of $\mathbf{8}$ and related compounds, however, residues that interfere with $\mathbf{8}$ without significantly affecting acetate or propionate activity have not been identified and the exact binding of the ligands remains somewhat unclear (Lee et al., 2008; Smith et al., 2011). It is however clear that the binding

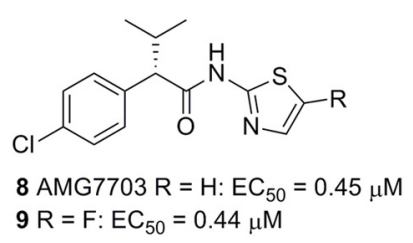

FIGURE 3 | Selective allosteric agonists of FFA2 (Amgen). Activities from an aequorin-based calcium assay are given (Lee et al., 2008). of 8 does not depend on $\operatorname{Arg} 180^{5.39}$ and $\operatorname{Arg} 255^{7.35}$, both of which serve as critical carboxylic acid anchoring points for the SCFAs (Swaminath et al., 2010; Smith et al., 2011). Interestingly, replacement of ECL2 of FFA2 by the corresponding sequence from FFA3 did not affect the potency of $\mathbf{8}$ or propionate, but resulted in reduced efficacy and abolishment of the cooperative effect between the two compounds (Smith et al., 2011). Attempts to optimize these compounds have been made, however, despite the synthesis of a large number of analogs with modifications introduced in all parts of the structure, it has turned out difficult to significantly improve their relatively moderate potency (Wang et al., 2010; Smith et al., 2011). Besides insufficient potency, the compounds also suffer from moderate solubility and poor pharmacokinetic properties (Wang et al., 2010), and are therefore of limited use as tool compounds for in vitro and in vivo studies.

No FFA2 or FFA3 modulators with desirable potency and properties have yet been reported in peer reviewed journals, but FFA2 ligands of interest have been described in recent patent applications. Euroscreen has patented a compound series of FFA2 agonists disclosing compounds with potency down to $\mathrm{EC}_{50}=$ $13 \mathrm{nM}$ (Figure 4) and claims their use in treatment of metabolic disorders (Hoveyda et al., 2010). A representative compound (12) increases glucose uptake in 3T3-L1 cells in a dose dependent manner. The increased glucose uptake was slight but significant at $1 \mu \mathrm{M}$ and almost doubled at $30 \mu \mathrm{M}$. The phenylacetamide 8 was not observed to increase glucose uptake in this assay. Furthermore, 12 dose-dependently inhibited lipolysis in isolated adipocytes. Again, $\mathbf{8}$ showed no effect in the assay. Compound $\mathbf{1 2}$ was also found to increase glucose uptake in isolated adipocytes by $100 \%$ already at $1 \mu \mathrm{M}$ concentration. Another representative

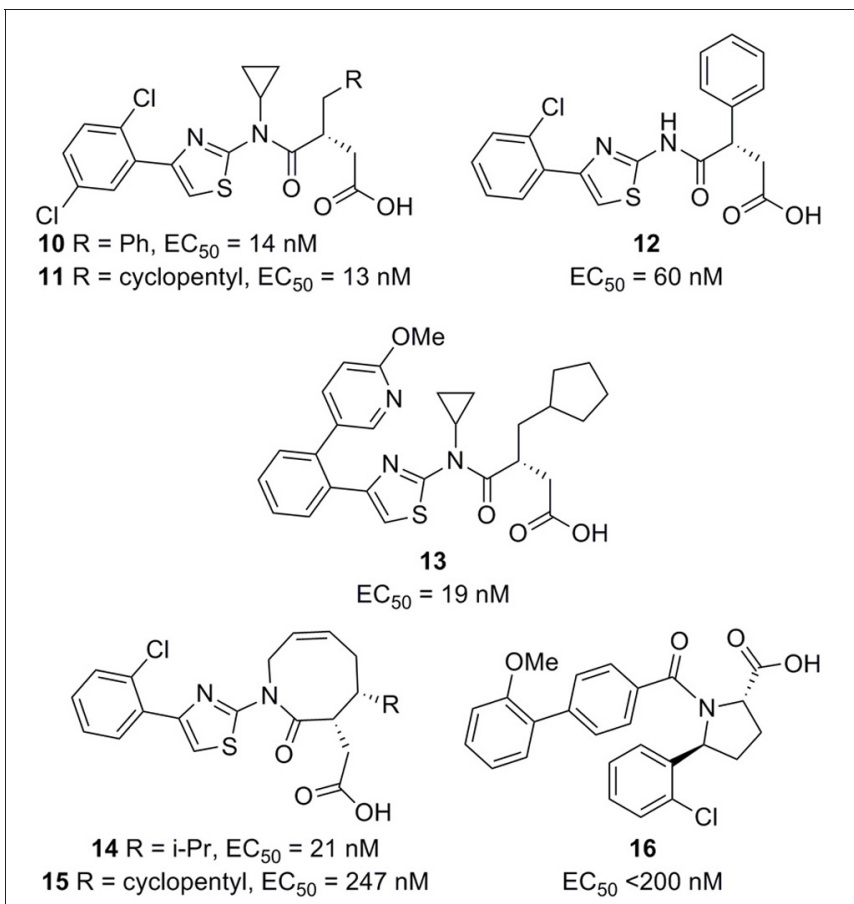

FIGURE 4 | FFA2 agonists (Euroscreen). The $\mathrm{EC}_{50}$ values are from GTP $\gamma \mathrm{S}$ binding in a scintillation proximity assay (Hoveyda et al., 2010, 2011a,b,c,d). 


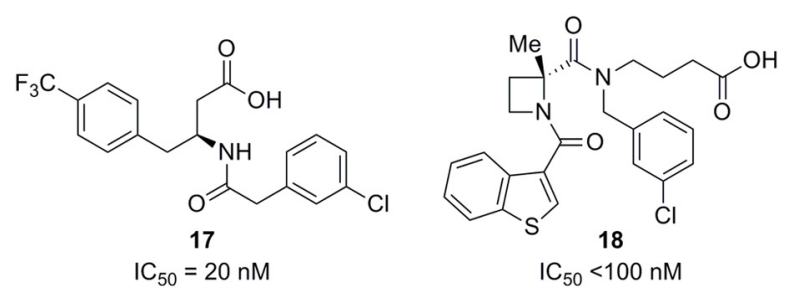

FIGURE 5 | FFA2 antagonists (Euroscreen and Galapagos). The $\mathrm{IC}_{50}$ value of $\mathbf{1 7}$ is from a GTP $\gamma \mathrm{S}$ assay in $\mathrm{CHO}$ cells expressing FFA2 using propionate $(600 \mu \mathrm{M})$ as agonist (Brantis et al., 2011). The $\mathrm{IC}_{50}$ value of 18 reflects a calcium mobilization assay and a GTP $\gamma$ S assay (Saniere et al., 2012).

(13) was found to increase GLP-1 secretion from NCI-H716 cells (Hoveyda et al., 2010). Euroscreen has moreover claimed the compound series for treatment of gastrointestinal disorders and inflammatory diseases, including IBD, and has found representatives to decrease colonic contractility and motility and to decrease TNF- $\alpha$ and IL-6 release from PBMCs stimulated with LPS (Hoveyda et al., 2011a,b). A series of constrained lactam analogs has appeared in a recent patent application (Hoveyda et al., 2011d), including compounds with $\mathrm{EC}_{50}$ down to $21 \mathrm{nM}(\mathbf{1 4})$ and one representative (15) demonstrated in concentrations from 0.1 to $30 \mu \mathrm{M}$ to significantly and dose dependently increased GLP-1 secretion from a rat lower intestinal cell preparation. A separate series of 5-aryl-2-acylpyrrollidinecarboxylic acid FFA2 agonists also patented by Euroscreen contains several members with $\mathrm{EC}_{50}<200 \mathrm{nM}$. Of these, 16 was found to inhibit isoprenalineinduced lipolysis in rat adipocytes and reduce the blood glucose level in $o b / o b$ mice after glucose challenge following 28 days of chronic treatment (Figure 4) (Hoveyda et al., 2011c).

Euroscreen has furthermore patented a series of FFA2 antagonists for treatment or prevention of inflammatory, gastrointestinal and metabolic disorders, including 17, which was disclosed with $\mathrm{IC}_{50}=10 \mathrm{nM}$ in a calcium-based assay and $20 \mathrm{nM}$ in a GTP $\gamma S$ assay (Figure 5). Homologous competition binding studies with tritiated 17 exhibited $\mathrm{pIC}_{50} \sim 8$ in a human FFA2 recombinant cell line and $\mathrm{pIC}_{50} \sim 6$ in neutrophils. The radiotracer was also displaced from the FFA2 transfected cells by propionate with $\mathrm{pIC}_{50} \sim 2.5$, suggesting orthosteric interaction (Brantis et al., 2011). This observation demonstrates that the orthosteric binding site can accommodate ligands that are larger than valeric acid (C5, Figure 1). It indeed appears reasonable to hypothesize that all ligands in Figures $\mathbf{4}$ and $\mathbf{5}$ act as orthosteric ligands and that their carboxylic acid residues are engaged in interactions similar to those of the endogenous SCFAs.

A series of azetidine FFA2 antagonists is claimed for treatment of inflammatory conditions and autoimmune, infectious, cardiometabolic, and proliferative diseases in a recent patent application from Galapagos (Saniere et al., 2012). The representative compound 18 exhibited $\mathrm{IC}_{50}$ below $100 \mathrm{nM}$ in a calcium mobilization assay, a GTP $\gamma \mathrm{S}$ binding assay, both using acetate at a concentration corresponding to $\mathrm{EC}_{80}$, and a neutrophil migration assay using acetate as chemoattractant.

There has been less activity directed toward development of selective FFA3 modulators. An early patent application from
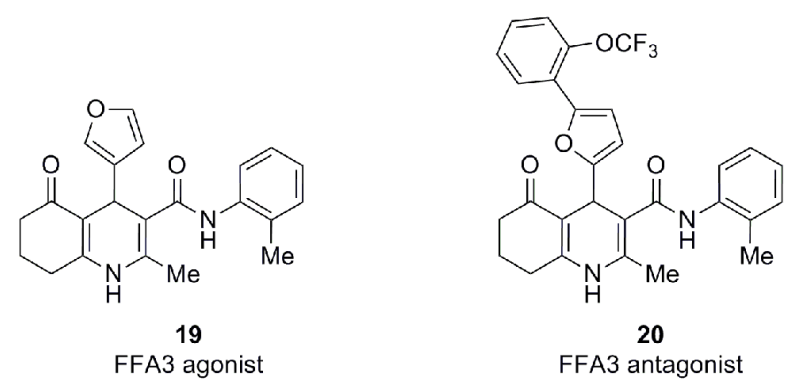

FFA3 antagonist

FIGURE 6 | FFA3 modulators (Arena) (Leonard et al., 2006).

Arena claims methods and compounds related to FFA3 (Leonard et al., 2006). The application describes results showing that FFA3 is highly expressed in human and mouse pancreas, that the receptor is upregulated in $d b / d b$ mice, compared to wild-type mice and leptin-deficient $o b / o b$ mice, and that it is expressed in the insulin-producing $\beta$-cell lines NIT-1, $\beta$ TC-6, and MIN6. Several compounds are disclosed as FFA3 agonists or antagonists. Cyclopropanecarboxylic acid, a mixed FFA2/FFA3 agonist with moderate selectivity for FFA3 (Schmidt et al., 2011), was found to inhibit insulin secretion from the murine insulinoma cell line MIN6. The patent application also discloses the structure of FFA3 agonists such as 19 (Figure 6) and FFA3 antagonists such as 20, but no indication of their potencies is given. The FFA3 agonist 19 reverses the beneficial effect on oral glucose tolerance test of the GPR119 agonist B111 (AR231453) in mice, which might imply that agonism is not the preferred mode of action.

\section{CONCLUSION}

It is clear that the intestinal microbiome has a significant influence on health (Kau et al., 2011). An illustrative example of this is provided by a recent study demonstrating that a lower number of colonic bacterial species is associated with higher body weight in pairs of lean and obese twins (Turnbaugh et al., 2009). A fiberrich diet has long been established as a significant contributor to good health. The gut microbiome is responsible for the fermentation of dietary fiber, which leads to production of SCFAs and several beneficial health effects. Recent results suggest that the SCFA receptors FFA2 and FFA3 are implicated in several of these health effects.

FFA2 and FFA3 were deorphanized at the same time as FFA1, but have received comparably less attention as drug targets. Accumulating evidence however indicates that the receptors are of interest as potential targets for treatment of various conditions and diseases related to immunology and metabolism. FFA2 plays a role in certain immune diseases where neutrophils are implicated, such as ulcerative colitis and Crohn's disease. Both FFA2 and FFA3 have been implicated with weight regulation and metabolic diseases like type 2 diabetes by several lines of evidence, although some contradictory results blurs the picture for FFA3. Both receptors are expressed in the intestines and it was recently reported that FFA2 mediates SCFA-promoted GLP-1 release. Results are described in recent patent applications indicating that FFA2 agonists indeed promote GLP-1 release and that 
they furthermore increase glucose uptake in adipocytes, thus providing support for the notion that FFA2 agonists could be of interest for the treatment of type 2 diabetes. Although the prospects look interesting, additional research is necessary to firmly establish the receptors as drug targets and the mode of action for drug candidates. Potent and selective tool compounds will be required for such studies, and recent

\section{REFERENCES}

Ballesteros, J. A., and Weinstein, H. W. (1995). "Integrated methods for the construction of three-dimensional models and computational probing of structure-function relations in G-protein coupled receptors," in Methods in Neuroscience, 25, eds S. C. Sealfon and P. M. Conn (San Diego, CA: Academic Press), 366-428.

Bjursell, M., Admyre, T., Goransson, M., Marley, A. E., Smith, D. M., Oscarsson, J., and Bohlooly, Y. M. (2011). Improved glucose control and reduced body fat mass in free fatty acid receptor 2-deficient mice fed a high-fat diet. Am. J. Physiol. Endocrinol. Metabol. 300, E211-E220.

Brantis, C. E., Ooms, F., and Bernard, J. (2011). Novel amino acid derivatives and their use as GPR43 receptor modulators. PCT Int. Appl. WO2011092284.

Briscoe, C. P., Peat, A. J., McKeown, S. C., Corbett, D. F., Goetz, A. S., Littleton, T. R., McCoy, D. C., Kenakin, T. P., Andrews, J. L., Ammala, C., Fornwald, J. A., Ignar, D. M., and Jenkinson, S. (2006). Pharmacological regulation of insulin secretion in MIN6 cells through the fatty acid receptor GPR40, identification of agonist and antagonist small molecules. Br. J. Pharmacol. 148, 619-628.

Briscoe, C. P., Tadayyon, M., Andrews, J. L., Benson, W. G., Chambers, J. K., Eilert, M. M., Ellis, C., Elshourbagy, N. A., Goetz, A. S., Minnick, D. T., Murdock, P. R., Sauls, H. R., Shabon, U., Spinage, L. D., Strum, J. C., Szekeres, P. G., Tan, K. B., Way, J. M., Ignar, D. M., Wilson, S., and Muir, A. I. (2003). The orphan G protein-coupled receptor GPR40 is activated by medium and long chain fatty acids. J. Biol. Chem. 278, 11303-11311.

Brown, A. J., Goldsworthy, S. M., Barnes, A. A., Eilert, M. M., Tcheang, L., Daniels, D., Muir, A. I., Wigglesworth, M. J., Kinghorn, I., Fraser, N. J., Pike, N. B., Strum, J. C., Steplewski, K. M., Murdock, P. R., Holder, J. C., Marshall, F. H., Szekeres, P. G., Wilson, S.,
Ignar, D. M., Foord, S. M., Wise, A., and Dowell, S. J. (2003). The orphan $\mathrm{G}$ protein-coupled receptors GPR41 and GPR43 are activated by propionate and other short chain carboxylic acids. J. Biol. Chem. 278, 11312-11319.

Brown, A. J., Jupe, S., and Briscoe, C. P. (2005). A family of fatty acid binding receptors. DNA Cell Biol. 24, 54-61.

Burant, C. F., Viswanathan, P., Marcinak, J., Cao, C., Vakilynejad, M., Xie, B., and Leifke, E. (2012). TAK-875 versus placebo or glimepiride in type 2 diabetes mellitus: a phase 2, randomised, double-blind, placebo-controlled trial. Lancet. 379, 1403-1411.

Christiansen, E., Due-Hansen, M. E., Urban, C., Grundmann, M., Schroder, R., Hudson, B. D., Milligan, G., Cawthorne, M. A., Kostenis, E., Kassack, M. U., and Ulven, T. (2012). Free fatty acid receptor 1 (FFA1/GPR40) agonists: mesylpropoxy appendage lowers lipophilicity and improves ADME properties. J. Med. Chem. 55, 6624-6628.

Christiansen, E., Due-Hansen, M. E., Urban, C., Merten, N., Pfleiderer, M., Karlsen, K. K., Rasmussen, S. S., Steensgaard, M., Hamacher, A., Schmidt, J., Drewke, C., Petersen, R. K., Kristiansen, K., Ullrich, S., Kostenis, E., Kassack, M. U., and Ulven, T. (2010). Structure-activity study of dihydrocinnamic acids and discovery of the potent FFAl (GPR40) agonist TUG-469. ACS Med. Chem. Lett. 1, 345-349.

Christiansen, E., Urban, C., Grundmann, M., Due-Hansen, M. E., Hagesaether, E., Schmidt, J., Pardo, L., Ullrich, S., Kostenis, E., Kassack, M. U., and Ulven, T. (2011). Identification of a potent and selective free fatty acid receptor 1 (FFA1/GPR40) agonist with favorable physicochemical and in vitro ADME properties. J. Med. Chem. 54, 6691-6703.

Christiansen, E., Urban, C., Merten, N., Liebscher, K., Karlsen, K. K., Hamacher, A., Spinrath, A., Bond, A. D., Drewke, C., Ullrich, S., Kassack, M. U., Kostenis, E.,

patent applications indicate that such tools might soon become available.

\section{ACKNOWLEDGMENTS}

The Danish Council for Strategic Research (grant 11-116196) and the Danish Council for Independent Research | Technology and Production (grant 09-070364) are thanked for financial support.

and Ulven, T. (2008). Discovery of potent and selective agonists for the free fatty acid receptor 1 (FFA1/GPR40), a potential target for the treatment of type II diabetes. J. Med. Chem. 51, 7061-7064.

Covington, D. K., Briscoe, C. A., Brown, A. J., and Jayawickreme, C. K. (2006). The G-protein-coupled receptor 40 family (GPR40GPR43) and its role in nutrient sensing. Biochem. Soc. Trans. 34, 770-773.

Dewulf, E. M., Cani, P. D., Neyrinck, A. M., Possemiers, S., Van Holle, A., Muccioli, G. G., Deldicque, L., Bindels, L. B., Pachikian, B. D., Sohet, F. M., Mignolet, E., Francaux, M., Larondelle, Y., and Delzenne, N. M. (2011). Inulin-type fructans with prebiotic properties counteract GPR43 overexpression and PPAR gamma-related adipogenesis in the white adipose tissue of highfat diet-fed mice. J. Nutr. Biochem. 22, 712-722.

Garrido, D. M., Corbett, D. F., Dwornik, K. A., Goetz, A. S., Littleton, T. R., McKeown, S. C., Mills, W. Y., Smalley, T. L., Briscoe, C. P., and Peat, A. J. (2006). Synthesis and activity of small molecule GPR40 agonists. Bioorg. Med. Chem. Lett. 16, 1840-1845.

Ge, H. F., Li, X. F., Weiszmann, J., Wang, P., Baribault, H., Chen, J. L., Tian, H., and Li, Y. (2008). Activation of $\mathrm{G}$ protein-coupled receptor 43 in adipocytes leads to inhibition of lipolysis and suppression of plasma free fatty acids. Endocrinology 149, 4519-4526.

Halpern, K. B., Veprik, A., Rubins, N., Naaman, O., and Walker, M. D. (2012). GPR41 gene expression is mediated by internal ribosome entry site (IRES)-dependent translation of bicistronic mRNA encoding GPR40 and GPR41 proteins. J. Biol. Chem. 287, 20154-20163.

Hirasawa, A., Hara, T., Katsuma, S., Adachi, T., and Tsujimoto, G. (2008). Free fatty acid receptors and drug discovery. Biol. Pharm. Bull. 31, 1847-1851.

Hirasawa, A., Tsumaya, K., Awaji, T., Katsuma, S., Adachi, T., Yamada, M., Sugimoto, Y., Miyazaki, S., and
Tsujimoto, G. (2005). Free fatty acids regulate gut incretin glucagonlike peptide-1 secretion through GPR120. Nat. Med. 11, 90-94.

Hong, Y. H., Nishimura, Y., Hishikawa, D., Tsuzuki, H., Miyahara, H., Gotoh, C., Choi, K. C., Feng, D. D., Chen, C., Lee, H. G., Katoh, K., Roh, S. G., and Sasaki, S. (2005) Acetate and propionate short chain fatty acids stimulate adipogenesis via GPCR43. Endocrinology 146, 5092-5099.

Hou, J. K., Abraham, B., and El-Serag, H. (2011). Dietary intake and risk of developing inflammatory bowel disease: a systematic review of the literature. Am. J. Gastroenterol. 106, 563-573.

Houze, J. B., Zhu, L., Sun, Y., Akerman, M., Qiu, W., Zhang, A. J., Sharma, R., Schmitt, M., Wang, Y., Liu, J., Liu, J., Medina, J. C., Reagan, J. D., Luo, J., Tonn, G., Zhang, J., Lu, J. Y., Chen, M., Lopez, E., Nguyen, K., Yang, L., Tang, L., Tian, H., Shuttleworth, S. J., and Lin, D. C. H. (2012). AMG 837, a potent, orally bioavailable GPR40 agonist. Bioorg. Med. Chem. Lett. 22, 1267-1270.

Hoveyda, H., Brantis, C. E., Dutheuil, G., Zoute, L., Schils, D., and Bernard, J. (2010). Compounds, pharmaceutical composition and methods for use in treating metabolic disorders. PCT Int. Appl. WO2010066682.

Hoveyda, H., Brantis, C. E., Dutheuil, G., Zoute, L., Schils, D., and Bernard, J. (2011a). Compounds, pharmaceutical composition and methods for use in treating inflammatory diseases. PCT Int. Appl. WO2011076734.

Hoveyda, H., Brantis, C. E., Dutheuil, G., Zoute, L., Schils, D., and Fraser, G. (2011b). Compounds, pharmaceutical composition and methods for use in treating for use in the treatment of gastrointestinal disorders. PCT Int. Appl. WO2011076732.

Hoveyda, H., Schils, D., Zoute, L., and Parcq, J. (2011c). Pyrrolidine or thiazolidine carboxylic acid derivatives, pharmaceutical compositions and methods for use as in treating metabolic disorders as agonists of G-protein coupled 
receptor 43 (GPR43). PCT Int. Appl. WO2011073376.

Hoveyda, H., Zoute, L., and Lenoir, F. (2011d). Azepanes, azocanes and related compounds as GPR43 modulators and their preparation and use for the treatment of inflammatory, gastrointestinal and metabolic disorders. PCT Int. Appl. WO2011151436.

Hudson, B. D., Christiansen, E., Tikhonova, I. G., Grundmann, M., Kostenis, E., Adams., D. R., Ulven, T., and Milligan, G. (2012). Chemically engineering ligand selectivity at the free fatty acid receptor 2 based on pharmacological variation between species orthologs. FASEB J. doi: 10.1096/fj.12-213314. [Epub ahead of print].

Hudson, B. D., Smith, N. J., and Milligan, G. (2011). "Experimental challenges to targeting poorly characterized GPCRs: uncovering the therapeutic potential for free fatty acid receptors," in Advances in Pharmacology, Vol. 62, ed R. R. Neubig (Burlington: Academic Press), 175-218.

Humphries, P. S., Benbow, J. W., Bonin, P. D., Boyer, D., Doran, S. D., Frisbie, R. K., Piotrowski, D. W., Balan, G., Bechle, B. M., Conn, E. L., Dirico, K. J., Oliver, R. M., Soeller, W. C., Southers, J. A., and Yang, X. J. (2009). Synthesis and SAR of 12 3, 4-tetrahydroisoquinolin-1ones as novel G-protein-coupled receptor 40 (GPR40) antagonists. Bioorg. Med. Chem. Lett. 19, 2400-2403.

Ichimura, A., Hirasawa, A., Hara, T., and Tsujimoto, G. (2009). Free fatty acid receptors act as nutrient sensors to regulate energy homeostasis. Prostaglandins Other Lipid Mediat. $89,82-88$.

Ichimura, A., Hirasawa, A., PoulainGodefroy, O., Bonnefond, A., Hara, T., Yengo, L., Kimura, I., Leloire, A., Liu, N., Iida, K., Choquet, H., Besnard, P., Lecoeur, C., Vivequin, S., Ayukawa, K., Takeuchi, M., Ozawa, K., Tauber, M., Maffeis, C., Morandi, A., Buzzetti, R., Elliott, P., Pouta, A., Jarvelin, M.-R., Korner, A., Kiess, W., Pigeyre, M., Caiazzo, R., Van Hul, W., Van Gaal, L., Horber, F., Balkau, B., Levy-Marchal, C., Rouskas, K., Kouvatsi, A., Hebebrand, J., Hinney, A., Scherag, A., Pattou, F., Meyre, D., Koshimizu, T.-A., Wolowczuk, I., Tsujimoto, G., and Froguel, P. (2012). Dysfunction of lipid sensor GPR120 leads to obesity in both mouse and human. Nature 483, 350-354.
Itoh, Y., Kawamata, Y., Harada, M., Kobayashi, M., Fujii, R., Fukusumi, S., Ogi, K., Hosoya, M., Tanaka, Y., Uejima, H., Tanaka, H., Maruyama, M., Satoh, R., Okubo, S., Kizawa, H., Komatsu, H., Matsumura, F., Noguchi, Y., Shinobara, T., Hinuma, S., Fujisawa, Y., and Fujino, M. (2003). Free fatty acids regulate insulin secretion from pancreatic beta cells through GPR40. Nature 422, 173-176.

Karaki, S., Mitsui, R., Hayashi, H., Kato, I., Sugiya, H., Iwanaga, T., Furness, J. B., and Kuwahara, A. (2006). Short-chain fatty acid receptor, GPR43, is expressed by enteroendocrine cells and mucosal mast cells in rat intestine. Cell Tissue Res. 324, 353-360.

Karaki, S. I., Tazoe, H., Hayashi, H., Kashiwabara, H., Tooyama, K., Suzuki, Y., and Kuwahara, A. (2008). Expression of the shortchain fatty acid receptor, GPR43, in the human colon. J. Mol. Histol. 39, 135-142.

Karra, E., and Batterham, R. L. (2010). The role of gut hormones in the regulation of body weight and energy homeostasis. Mol. Cell. Endocrinol. 316, 120-128.

Kau, A. L., Ahern, P. P., Griffin, N. W., Goodman, A. L., and Gordon, J. I. (2011). Human nutrition, the gut microbiome and the immune system. Nature 474, 327-336.

Kebede, M. A., Alquier, T., Latour, M. G., and Poitout, V. (2009). Lipid receptors and islet function: therapeutic implications? Diabetes Obes. Metab. 11, 10-20.

Kimura, I., Inoue, D., Maeda, T., Hara, T., Ichimura, A., Miyauchi, S., Kobayashi, M., Hirasawa, A., and Tsujimoto, G. (2011). Short-chain fatty acids and ketones directly regulate sympathetic nervous system via $G$ protein-coupled receptor 41 (GPR41). Proc. Natl. Acad. Sci. U.S.A. 108, 8030-8035.

Kotarsky, K., Nilsson, N. E., Flodgren, E., Owman, C., and Olde, B. (2003). A human cell surface receptor activated by free fatty acids and thiazolidinedione drugs. Biochem. Biophys. Res. Commun. 301, 406-410.

Le Poul, E., Loison, C., Struyf, S., Springael, J. Y., Lannoy, V., Decobecq, M. E., Brezillon, S., Dupriez, V., Vassart, G., Van Damme, J., Parmentier, M., and Detheux, M. (2003). Functional characterization of human receptors for short chain fatty acids and their role in polymorphonuclear cell activation. J. Biol. Chem. 278, 25481-25489.
Lee, T., Schwandner, R., Swaminath, G., Weiszmann, J., Cardozo, M. Greenberg, J., Jaeckel, P., Ge, H F., Wang, Y. C., Jiao, X. Y., Liu, J., Kayser, F., Tian, H., and Li, Y. (2008). Identification and functional characterization of allosteric agonists for the $G$ protein-coupled receptor FFA2. Mol. Pharmacol. 74, 1599-1609.

Leonard, J. N., Chu, Z. L., Bruce, M. A., and Boatman, P. D. (2006). GPR41 and modulators thereof for the treatment of insulinrelated disorders. PCT Int. Appl. WO2006052566.

Liaw, C. W., and Connolly, D. T. (2009). Sequence polymorphisms provide a common consensus sequence for GPR41 and GPR42. DNA Cell Biol. 28, 555-560.

Maslowski, K. M., Vieira, A. T., Ng, A., Kranich, J., Sierro, F., Yu, D., Schilter, H. C., Rolph, M. S., Mackay, F., Artis, D., Xavier, R. J., Teixeira, M. M., and Mackay, C. R. (2009). Regulation of inflammatory responses by gut microbiota and chemoattractant receptor GPR43. Nature 461, 1282-1287.

Medina, V., Edmonds, B., Young, G. P., James, R., Appleton, S., and Zalewski, P. D. (1997). Induction of caspase- 3 protease activity and apoptosis by butyrate and trichostatin, A (Inhibitors of histone deacetylase): dependence on protein synthesis and synergy with a mitochondrial/cytochrome c-dependent pathway. Cancer Res. 57, 3697-3707.

Mikami, S., Kitamura, S., Negoro, N., Sasaki, S., Suzuki, M., Tsujihata, Y., Miyazaki, T., Ito, R., Suzuki, N., Miyazaki, J., Santou, T., Kanzaki, N., Funami, M., Tanaka, T., Yasuma, T., and Momose, Y. (2012). Discovery of phenylpropanoic acid derivatives containing polar functionalities as potent and orally bioavailable G protein-coupled receptor 40 agonists for the treatment of type 2 diabetes. J. Med. Chem. 55, 3756-3776.

Milligan, G., Stoddart, L. A., and Brown, A. J. (2006). G proteincoupled receptors for free fatty acids. Cell. Signal. 18, 1360-1365.

Negoro, N., Sasaki, S., Ito, M., Kitamura, S., Tsujihata, Y., Ito, R., Suzuki, M., Takeuchi, K., Suzuki, N., Miyazaki, J., Santou, T., Odani, T., Kanzaki, N., Funami, M., Tanaka, T., Yasuma, T., and Momose, Y. (2012). Identification of fused-ring alkanoic acids with improved pharmacokinetic profiles that act as $G$ protein-coupled receptor 40/free fatty acid recptor 1 agonists. J. Med. Chem. 55, 1538-1552.
Negoro, N., Sasaki, S., Mikami, S., Ito, M., Suzuki, M., Tsujihata, Y., Ito, R., Harada, A., Takeuchi, K., Suzuki, N., Miyazaki, J., Santou, T., Odani, T., Kanzaki, N., Funami, M., Tanaka, T., Kogame, A., Matsunaga, S., Yasuma, T., and Momose, Y. (2010). Discovery of TAK-875, a potent, selective, and orally bioavailable GPR40 agonist. ACS Med. Chem. Lett. 1, 290-294.

Nilsson, N. E., Kotarsky, K., Owman, C., and Olde, B. (2003). Identification of a free fatty acid receptor, $\mathrm{FFA}_{2} \mathrm{R}$, expressed on leukocytes and activated by shortchain fatty acids. Biochem. Biophys. Res. Commun. 303, 1047-1052.

Oh, D. Y., Talukdar, S., Bae, E. J., Imamura, T., Morinaga, H., Fan, W. Q., Li, P. P., Lu, W. J., Watkins, S. M., and Olefsky, J. M. (2010). GPR120 is an omega3 fatty acid receptor mediating potent anti-inflammatory and insulin-sensitizing effects. Cell 142, 687-698.

Psaltopoulou, T., Ilias, I., and Alevizaki, M. (2010). The role of diet and lifestyle in primary, secondary, and tertiary diabetes prevention: a review of meta-analyses. Rev. Diabet. Stud. 7, 26-35.

Rosenkilde, M. M., Benned-Jensen, T., Frimurer, T. M., and Schwartz, T. W. (2010). The minor binding pocket: a major player in 7TM receptor activation. Trends Pharmacol. Sci. 31, 567-574.

Samuel, B. S., Shaito, A., Motoike, T., Rey, F. E., Backhed, F., Manchester, J. K., Hammer, R. E., Williams, S. C., Crowley, J., Yanagisawa, M., and Gordon, J. I. (2008). Effects of the gut microbiota on host adiposity are modulated by the shortchain fatty-acid binding $G$ proteincoupled receptor, Gpr41. Proc. Natl. Acad. Sci. U.S.A. 105, 16767-16772.

Saniere, L. R. M., Pizzonero, M. R., Triballeau, N., Vandeghinste, N. E. R., De, V. S. I. J., Brys, R. C. X., and Pourbaix-L'ebraly, C. D. (2012). Preparation of azetidine derivatives as GPR43 antagonists useful in the treatment of metabolic and inflammatory diseases. PCT Int. Appl. WO2012098033.

Sasaki, S., Kitamura, S., Negoro, N., Suzuki, M., Tsujihata, Y., Suzuki, N., Santou, T., Kanzaki, N., Harada, M., Tanaka, Y., Kobayashi, M., Tada, N., Funami, M., Tanaka, T., Yamamoto, Y., Fukatsu, K., Yasuma, T., and Momose, Y. (2011). Design, synthesis, and biological activity of potent and orally available $\mathrm{G}$ protein-coupled receptor 40 agonists. J. Med. Chem. 54, 1365-1378. 
Sawzdargo, M., George, S. R., Nguyen, T., Xu, S. J., Kolakowski, L. F., and Odowd, B. F. (1997). A cluster of four novel human $G$ proteincoupled receptor genes occurring in close proximity to $\mathrm{CD} 22$ gene on chromosome 19q13.1. Biochem. Biophys. Res. Commun. 239, 543-547.

Schmidt, J., Smith, N. J., Christiansen, E., Tikhonova, I. G., Grundmann, M., Hudson, B. D., Ward, R. J., Drewke, C., Milligan, G., Kostenis, E., and Ulven, T. (2011). Selective orthosteric free fatty acid receptor 2 (FFA2) agonists. identification of the structural and chemical requirements for selective activations of FFA2 versus FFA3. J. Biol. Chem. 286, 10628-10640.

Shimpukade, B., Hudson, B. D., Hovgaard, C. K., Milligan, G., and Ulven, T. (2012). Discovery of a potent and selective GPR120 agonist. J. Med. Chem. 55, 4511-4515.

Sina, C., Gavrilova, O., Forster, M., Till, A., Derer, S., Hildebrand, F., Raabe, B., Chalaris, A., Scheller, J., Rehmann, A., Franke, A., Ott, S., Hasler, R., Nikolaus, S., Folsch, U. R., Rose-John, S., Jiang, H. P., Li, J., Schreiber, S., and Rosenstiel, P. (2009). G protein-coupled receptor 43 is essential for neutrophil recruitment during intestinal inflammation. J. Immunol. 183, 7514-7522.

Sleeth, M. L., Thompson, E. L., Ford, H. E., Zac-Varghese, S. E. K., and Frost, G. (2010). Free fatty acid receptor 2 and nutrient sensing: a proposed role for fibre, fermentable carbohydrates and short-chain fatty acids in appetite regulation. Nutr. Res. Rev. $23,135-145$.

Smith, N. J., Ward, R. J., Stoddart, L. A., Hudson, B. D., Kostenis, E., Ulven, T., Morris, J. C., Trankle, C., Tikhonova, I. G., Adams, D. R., and Milligan, G. (2011). Extracellular loop 2 of the free fatty acid receptor 2 mediates allosterism of a phenylacetamide ago-allosteric modulator. Mol. Pharmacol. 80, 163-173.

Song, F. B., Lu, S. F., Gunnet, J., Xu, J. Z., Wines, P., Proost, J., Liang, Y., Baumann, C., Lenhard, J., Murray, W. V., Demarest, K. T., and Kuo,
G. H. (2007). Synthesis and biological evaluation of 3-aryl-3-(4phenoxy)-propionic acid as a novel series of $\mathrm{G}$ protein-coupled receptor 40 agonists. J. Med. Chem. 50, 2807-2817.

Stoddart, L. A., Smith, N. J., Jenkins, L., Brown, A. J., and Milligan, G. (2008a). Conserved polar residues in transmembrane domains, V, VI, and VII of free fatty acid receptor 2 and free fatty acid receptor 3 are required for the binding and function of short chain fatty acids. J. Biol. Chem. 283, 32913-32924.

Stoddart, L. A., Smith, N. J., and Milligan, G. (2008b). International union of pharmacology. LXXI. Free fatty acid receptors FFAl, -2 , and-3, pharmacology and pathophysiological functions. Pharmacol. Rev. 60, 405-417.

Sum, C. S., Tikhonova, I. G., Neumann, S., Engel, S., Raaka, B. M., Costanzi, S., and Gershengorn, M. C. (2007). Identification of residues important for agonist recognition and activation in GPR40. J. Biol. Chem. 282, 29248-29255.

Suzuki, T., Igari, S. I., Hirasawa, A., Hata, M., Ishiguro, M., Fujieda, H., Itoh, Y., Hirano, T., Nakagawa, H., Ogura, M., Makishima, M., Tsujimoto, G., and Miyata, N. (2008). Identification of $\mathrm{G}$ proteincoupled receptor 120-selective agonists derived from PPAR gamma agonists. J. Med. Chem. 51, 7640-7644.

Swaminath, G., Jaeckel, P., Guo, Q., Cardozo, M., Weiszmann, J., Lindberg, R., Wang, Y. C., Schwandner, R., and Li, Y. (2010). Allosteric rescuing of loss-offunction FFAR2 mutations. FEBS Lett. 584, 4208-4214.

Tan, C. P., Feng, Y., Zhou, Y. P., Eiermann, G. J., Petrov, A., Zhou, C. Y., Lin, S. N., Salituro, G., Meinke, P., Mosley, R., Akiyama, T. E., Einstein, M., Kumar, S., Berger, J. P., Mills, S. G., Thornberry, N. A., Yang, L. H., and Howard, A. D. (2008). Selective small-molecule agonists of $\mathrm{G}$ protein-coupled receptor 40 promote glucosedependent insulin secretion and reduce blood glucose in mice. Diabetes 57, 2211-2219.
Tang, Y., Chen, Y. K., Jiang, H. M., Robbins, G. T., and Nie, D. T. (2011). G-protein-coupled receptor for short-chain fatty acids suppresses colon cancer. Int. J. Cancer $128,847-856$.

Tikhonova, I. G., Sum, C. S., Neumann, S., Engel, S., Raaka, B. M., Costanzi, S., and Gershengorn, M. C. (2008). Discovery of novel Agonists and antagonists of the free fatty acid receptor 1 (FFAR1) using virtual screening. J. Med. Chem. 51, 625-633.

Tolhurst, G., Heffron, H., Lam, Y. S., Parker, H. E., Habib, A. M., Diakogiannaki, E., Cameron, J., Grosse, J., Reimann, F., and Gribble, F. M. (2012). Short-chain fatty acids stimulate glucagon-like peptide-1 secretion via the G-protein-coupled receptor FFAR2. Diabetes 61, 364-371.

Topping, D. L., and Clifton, P. M. (2001). Short-chain fatty acids and human colonic function: roles of resistant starch and nonstarch polysaccharides. Physiol. Rev. 81, 1031-1064.

Turnbaugh, P. J., Hamady, M., Yatsunenko, T., Cantarel, B. L., Duncan, A., Ley, R. E., Sogin, M. L., Jones, W. J., Roe, B. A., Affourtit, J. P., Egholm, M., Henrissat, B., Heath, A. C., Knight, R., and Gordon, J. I. (2009). A core gut microbiome in obese and lean twins. Nature 457, U480-U487.

Vinolo, M. A., Ferguson, G. J., Kulkarni, S., Damoulakis, G., Anderson, K., Bohlooly.-Y. M., Stephens, L., Hawkins, P. T., and Curi, R. (2011). SCFAs induce mouse neutrophil chemotaxis through the GPR43 receptor. PLoS ONE 6. doi: 10.1371/ journal.pone. 0021205

Voltolini, C., Battersby, S., Etherington, S. L., Petraglia, F., Norman, J. E., and Jabbour, H. N. (2012). A novel antiinflammatory role for the shortchain fatty acids in human labor. Endocrinology 153, 395-403.

Wang, J. H., Wu, X. S., Simonavicius, N., Tian, H., and Ling, L. (2006). Medium-chain fatty acids as ligands for orphan $G$ protein-coupled receptor GPR84. J. Biol. Chem. 281, 34457-34464.

Wang, Y. C., Jiao, X. Y., Kayser, F., Liu, J. W., Wang, Z. Y., Wanska,
M., Greenberg, J., Weiszmann, J., Ge, H. F., Tian, H., Wong, S., Schwandner, R., Lee, T., and Li, Y. (2010). The first synthetic agonists of FFA2, Discovery and SAR of phenylacetamides as allosteric modulators. Bioorg. Med. Chem. Lett. 20, 493-498.

Wellendorph, P., Johansen, L. D., and Brauner-Osborne, H. (2009). Molecular pharmacology of promiscuous seven transmembrane receptors sensing organic nutrients. Mol. Pharmacol. 76, 453-465.

Xiong, Y. M., Miyamoto, N., Shibata, K., Valasek, M. A., Motoike, T., Kedzierski, R. M., and Yanagisawa, M. (2004). Short-chain fatty acids stimulate leptin production in adipocytes through the G proteincoupled receptor GPR41. Proc. Natl. Acad. Sci. U.S.A. 101, 1045-1050.

Zaibi, M. S., Stocker, C. J., O'dowd, J., Davies, A., Bellahcene, M., Cawthorne, M. A., Brown, A. J. H., Smith, D. M., and Arch, J. R. S. (2010). Roles of GPR41 and GPR43 in leptin secretory responses of murine adipocytes to short chain fatty acids. FEBS Lett. 584, 2381-2386.

Conflict of Interest Statement: The author declares that the research was conducted in the absence of any commercial or financial relationships that could be construed as a potential conflict of interest.

Received: 15 November 2011; accepted: 20 August 2012; published online: 02 October 2012.

Citation: Ulven $T$ (2012) Short-chain free fatty acid receptors FFA2/GPR43 and FFA3/GPR41 as new potential therapeutic targets. Front. Endocrin. 3:111. doi: 10.3389/fendo.2012.00111

This article was submitted to Frontiers in Molecular and Structural Endocrinology, a specialty of Frontiers in Endocrinology. Copyright (c) 2012 Ulven. This is an open-access article distributed under the terms of the Creative Commons Attribution License, which permits use, distribution and reproduction in other forums, provided the original authors and source are credited and subject to any copyright notices concerning any thirdparty graphics etc. 